\title{
Analisis Kualitas Air Laut Sebagai Bahan Baku Garam di Provinsi Aceh
}

\author{
Bahagia $^{1^{*}}$ Afrizal $^{2}$ \\ ${ }^{1}$ Program Studi Teknik Lingkungan Fakultas Teknik, Universitas Serambi Mekkah \\ ${ }^{2}$ Bidang Program Pemberdayaan Ekonomi Masyarakat Pesisir, Dinas Kelautan dan Perikanan Aceh, \\ Pemerintah Aceh \\ *Koresponden email: bahagia@serambimekkah.ac.id
}

Diterima: 23 Mei 2019

Disetujui: 30 Juni 2019

\begin{abstract}
Currently barriers are still faced by salt farmers because they still use traditional technology in salt production so traditional farmers are less competitive than other modern salt products. The method of data collection was carried out by analyzing sea water quality survey and test at the Research and Development Agency of the Industrial Research and Standardization Center of Industrial in Banda Aceh. This study aims to obtain the results of measuring the quality of sea water that will be used as old water as raw material for salt. The results showed that the highest degree of Bauma came from the sample of Alue Rambut Lembah Sabil and Sejahtera Manggeng in the amount of $4^{\circ} \mathrm{Be}$. Furthermore, the highest $\mathrm{NaCl}$ level originated in the Sejahtera Mangeng sample by $3 \%$, the highest iodine (KiO3) from the Sejahtera Manggeng sample of $0.421 \mathrm{mg} / \mathrm{kg}$. The biggest lead $(\mathrm{Pb})$ test results came from the Sejahtera Mangeng sample of $0.2224 \mathrm{mg} / \mathrm{L}$. Furthermore, the test results of Cadmium (Cd), Water Mercury (Hg) and Arsenic (As) with the AAS method are at the detection limit of the test equipment at $<0,0004 \mathrm{mg} / \mathrm{L},<0,0005 \mathrm{mg} / \mathrm{L}$ and $<00002 \mathrm{mg} / \mathrm{L}$.
\end{abstract}

Keywords: Salt, Salt Farmers, Production, Traditional, Sea Water Quality

Abstrak: Hambatan masih dihadapi oleh petambak garam karena mereka masih menggunakan teknologi tradisional dalam produksi garam sehingga petambak tradisional kalah saing dari produk garam modern lain. Metode penelitian dilakukan dengan survey dan uji kualitas air laut pada Badan Penelitian dan Pengembangan Industri Balai Riset dan Standarisasi Industri Banda Aceh. Penelitian ini bertujuan untuk mendapatkan pengukuran kualitas air laut yang akan digunakan sebagai air tua sebagai bahan baku garam. Hasil penelitian menunjukan bahwa Derajat Bauma paling tinggi berasal dari sampel Alue Rambut Lembah Sabil dan Sejahtera Mangeng sebesar $4{ }^{\circ}$ Be. Selanjutnya kadar $\mathrm{NaCl}$ paling besar berasal di sampel Sejahtera Mangeng sebesar 3\%, Iodium (KiO3) paling tinggi dari sampel Sejahtera Mangeng sebesar $0,421 \mathrm{mg} / \mathrm{kg}$. Hasil uji timbal $(\mathrm{Pb})$ paling besar berasal dari sampel Sejahtera Mangeng sebesar 0,2224 mg/L. Selanjutnya hasil uji Kadmium (Cd), Air Raksa (Hg) dan Arsen (As) dengan metode AAS berada pada posisi batas deteksi alat uji masing-masing sebesar $<0,0004 \mathrm{mg} / \mathrm{L},<0,0005 \mathrm{mg} / \mathrm{L}$ dan $<0,0002 \mathrm{mg} / \mathrm{L}$.

Kata kunci: Garam, Petambak Garam, Produksi, Tradisional, Kualitas Air Laut

\section{Pendahuluan}

Air merupakan zat yang penting bagi semua kehidupan yang hidup di bumi, tetapi tidak di planet lain. Menurut Dini Purbani (2006) air menutupi hampir $71 \%$ permukaan bumi. Saat ini jumlah air di bumi mencapai 1,4 triliun kubik (330 juta mil ${ }^{3}$ ). Dalam menentukan kualitas air, dilakukan pengamatan berdasarkan parameter air yaitu kimia, fisika dan biologi. Parameter kimia meliputi $\mathrm{pH}, \mathrm{O}_{2}$ terlarut dan $\mathrm{CO}_{2}$ bebas. Parameter fisika meliputi suhu, tingkat 
Tabel 1. Standar baku mutu air laut untuk biota laut

\begin{tabular}{clcc}
\hline No & Parameter & Satuan & Baku Mutu \\
\hline 1 & Raksa (Hg) & $\mathrm{mg} / \mathrm{l}$ & 0,001 \\
2 & Arsen (As) & $\mathrm{mg} / \mathrm{l}$ & 0,012 \\
3 & Cadmium & $\mathrm{mg} / \mathrm{l}$ & 0,001 \\
& (Cd) & & \\
4 & Seng (Zn) & $\mathrm{mg} / \mathrm{l}$ & 0,05 \\
\hline
\end{tabular}

kecerahan, tingkat kekeruhan dan tingkat kedalaman. Parameter biologi meliputi plankton dan bentos. Untuk melihat kualitas air dilakukan pengukuran pada ekosistem perairan seperti sungai, laut, kolam waduk, teluk, danau, semananjung, delta dan perairan lainnya.

Garam merupakan benda padat berwarna putih berbentuk kristal yang terdiri dari kumpulan senyawa dengan bagian terbesar Natrium Chlorida $(>80 \%)$ serta Magnesium Chlorida, Magnesium sulfat, dan Calsium Chlorida. Sumber garam di alam berasal dari air laut, air deposit dalam tanah, danau asin, sumber air dalam tanah dan tambang garam (Burhanuddin $\mathrm{S}$, 2001).

Seiring dengan pertambahan penduduk dan perkembangan industri di Indonesia kebutuhan garam nasional semakin meningkat. Menurut data Direktorat Kimia Hilir Kementerian Perindustrian (2011), produksi garam nasional di tahun 2010 mengalami penurunan drastis sebesar $2 \%$ dari kapasitas produksi (1,2 juta ton). Jumlah produksi tersebut hanya sekitar 23.000 ton. Penyebab penurunan jumlah produksi garam tersebut karena curah hujan tinggi yang dapat mengacaukan siklus produksi garam. Iklim yang tak menentu membuat produksi garam nasional benarbenar anjlok, padahal dalam kondisi normal, musim garam (kemarau) di Indonesia 4,5-5 bulan setiap tahunnya.

Menurut data Direktorat Kimia Hilir Kementerian Perindustrian (2011), melorotnya produksi garam tahun 2010 telah berdampak melonjaknya impor garam konsumsi hingga 4 kali lipat. Tahun 2009 impor garam konsumsi hanya sebesar 150.000 ton, sementara tahun 2010 mencapai 600.000 ton. Selama ini kebutuhan garam industri nasional pertahunnya bisa mencapai 2,6-2,8 juta ton mencakup kebutuhan industri untuk industri chlor alkali plant (CAP). Untuk kebutuhan garam untuk industri CAP tersebut mencapai 1,6 juta ton yang semuanya impor. Sementara itu, kebutuhan garam untuk industri pangan atau pembersih bisa mencapai 500.000 ton. Kebutuhan garam untuk industri pengeboran bisa mencapai 125.000 ton dan kebutuhan industri lainnya 50.000 ton. Sementara kebutuhan garam untuk konsumsi rumah tangga mencapai 700.000 ton per tahun.

Saat ini ada permasalahan yang dialami oleh petambak garam dalam mengembangkan usaha garam rakyat yaitu masih menggunakan teknologi tradisional dalam produksi garam sehingga kalah saing dari produk garam daerah lain. Tujuan pengembangan garam rakyat untuk meningkatkan kesempatan kerja dan kesejahteraan petambak garam melalui kegiatan usaha produksi garam. Diharapkan kedepan, petambak garam akan berubah menjadi kelompok masyarakat yang mampu mengembangkan diri dalam peningkatan produksi garam. Untuk peningkatan produksi garam dan kualitas produk yang bagus sehingga bisa menjadi andalan bagi masyarakat Aceh.

Penelitian ini bertujuan untuk mendapatkan hasil pengukuran kualitas air laut sebagai air tua bahan baku pembuatan garam. Selanjutnya dilakukan uji laboratorium terhadap 7 paramater yaitu Derajat Baume, Kadar NaCL, Iodium (KiO3), Kadmium (Cd), Timbal (Pb), Air Raksa (Hg) dan Arsen (As).

\section{Tinjauan Pustaka}

Pemeriksaan kualitas air laut dapat dilakukan dengan dua cara, yaitu: pertama pengukuran kualitas parameter kimia (suhu, $\mathrm{O}_{2}$ terlarut, $\mathrm{CO}_{2}$ bebas, $\mathrm{pH}$, konduktivitas, kecerahan, alkalinitas) dan pengukuran parameter fisika. Kedua pengukuran kualitas air parameter biologi (benthos dan plankton) (Sihotang, 2006). Secara umum pengukuran kualitas air menggunakan metode purposive sampling, yaitu pengambilan sampel dengan memperhatikan berbagai pertimbangan keadaan dan kondisi daerah pengamatan (Effendi. H, 2003).

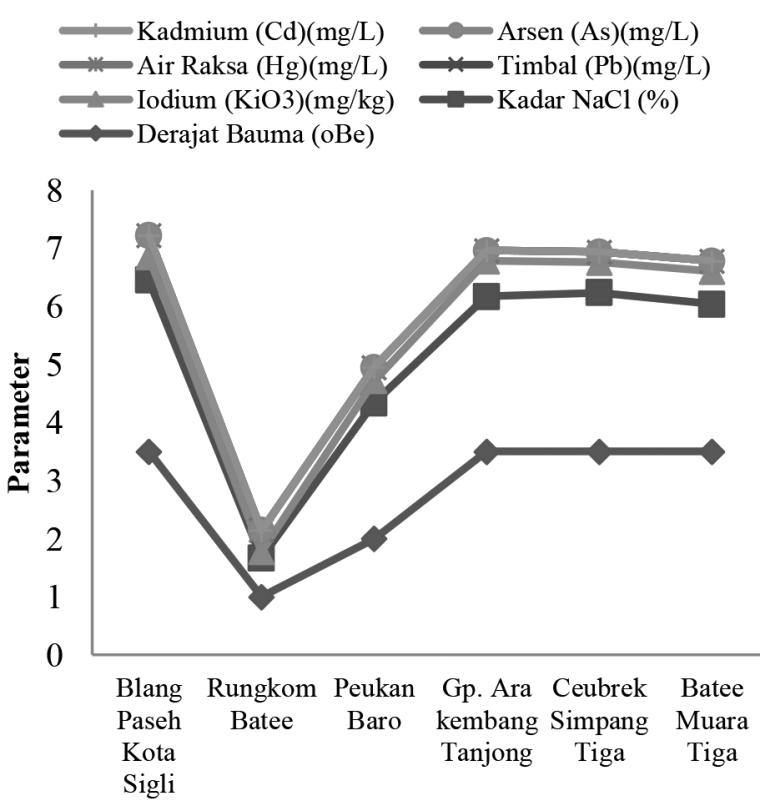

Gambar 1. Hasil uji kualitas air garam di Kabupaten Pidie 


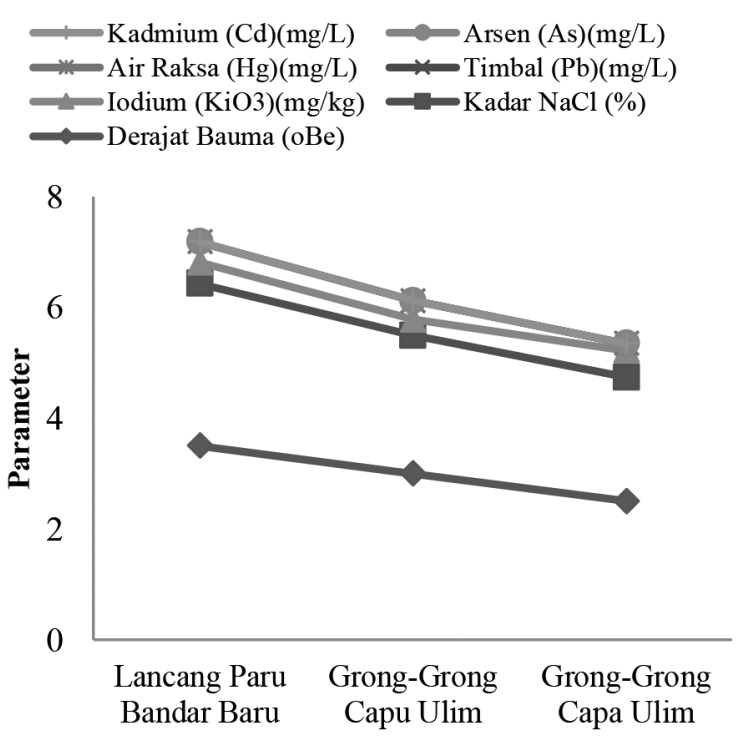

Gambar 2. Hasil uji kualitas air garam di Kabupaten Pidie Jaya

Banyak logam berat terakumulasi kedalam organisme dan beberapa juga terakumulasi dalam rantai makanan (Andersen 1996; Han dkk.1994; Scheifler, dkk.2002). Menurut Subarijanti, H. U (2005), umumnya kadar fosfat di dalam perairan dalam jumlah kecil yaitu $0,05-0,20 \mathrm{mg} / \mathrm{L}$ dan fosfat mempunyai mobilitas yang sangat kecil. Kadar fosfat yang tinggi dalam perairan alami dapat memicu pertumbuhan tanaman air dan alga secara berlebihan.

Berbagai faktor dapat mempengaruhi sistem temperatur ekosistem air antara lain pertukaran panas antara air dengan udara sekelilingnya, sistem kerja kanopi (tutupan oleh vegetasi) dari pepohonan yang tumbuh di tepi, intensitas cahaya matahari dan ketinggian geografis (Barus, 2003). Fotosintesis dapat berlangsung sempurna apabila cahaya matahari dapat menembus suatu perairan dengan kedalaman tertentu, sehingga menyebabkan kecerahan perairan tersebut. Menurut Chakroff dalam Syukur (2002) kecerahan mendukung apabila pinggan secchi disk mencapai 20$40 \mathrm{~cm}$ dari permukaan air laut.

Garam yang kita dikonsumsi manusia setiap hari merupakan senyawa kimia Natrium Klorida $(\mathrm{NaCl})$ sebagai bagian terbesarnya dan Kalsium Sulfat (gips) CaSO4, Magnesium Sulfat (MgSO4), Magnesium Klorida $(\mathrm{MgCl} 2)$ sebagai pengotor (Sutrisnanto D, 2001). Kristal garam dihasilkan dari air laut diuapkan, atau garam krosok. Garam dapur yang belum dimurnikan hasil penguapan masih mengandung zat-zat pengotor seperti $\mathrm{Ca}^{2+}, \mathrm{Mg}^{2+}, \mathrm{Al}^{3+}, \mathrm{Fe}, \mathrm{SO}^{2-}$, $\mathrm{I}, \mathrm{Br}$ (Cotton, dkk, 1989). Menurut Sutrisnanto, D (2001) garam yang kita kenal sehari-hari, adalah suatu kumpulan senyawa kimia dengan bagian terbesar terdiri dari Natrium Klorida $(\mathrm{NaCl})$ dengan pengotor terdiri dari Kalsium Sulfat (CaSO4), Magnesium Sulfat (MgSO4), Magnesium Klorida ( $\mathrm{MgCl} 2)$, dan lain-lain.

Peningkatan kualitas garam dapur dapat dilakukan dengan cara kristalisasi bertingkat, pencucian garam dan rekristalisasi. Pemurnian dengan penambahan bahan pengikat pengotor merupakan cara lain untuk meningkatkan kualitas garam. Tanpa adanya proses pemurnian, maka garam dapur yang dihasilkan melalui penguapan air laut masih bercampur dengan senyawa lain yang terlarut, seperti $\mathrm{MgSO} 4, \mathrm{MgCl} 2$, $\mathrm{CaCO} 3, \mathrm{CaSO} 4, \mathrm{KBr}$ dan $\mathrm{KCl}$ dalam jumlah kecil (Jumaeri, 2003).

Usaha pembangunan di segala aspek telah memberikan dampak positif dan negatif. Salah satu dampak negatif tersebut telah mengakibatkan terjadinya peningkatan buangan limbah logam berat ke lingkungan kawasan pantai. Pembuangan logam berat ke lingkungan kawasan perairan seperti $\mathrm{Hg}, \mathrm{Cd}, \mathrm{Pb}, \mathrm{Fe}, \mathrm{Zn}, \mathrm{Cu}$ merupakan racun bagi organisme hidup bila berada dalam konsentrasi yang tinggi (Rahmat A1. Ramard A, 2016). Saat ini banyak logam berat terakumulasi kedalam organisme dan rantai makanan. Logam digolongkan kedalam dua kategori, yaitu logam berat dan logam ringan. Logam berat ialah logam yang mempunyai berat $5 \mathrm{~g}$ atau lebih untuk setiap $33 \mathrm{~cm} 3$, dengan sendirinya logam yang beratnya kurang dari 5 gr setiap cm3 termasuk logam ringan (Darmono, 1995). Baku mutu air laut untuk biota laut menurut keputusan Kementerian Lingkungan Hidup tahun 2004 lampiran III dapat dilihat pada Tabel 1

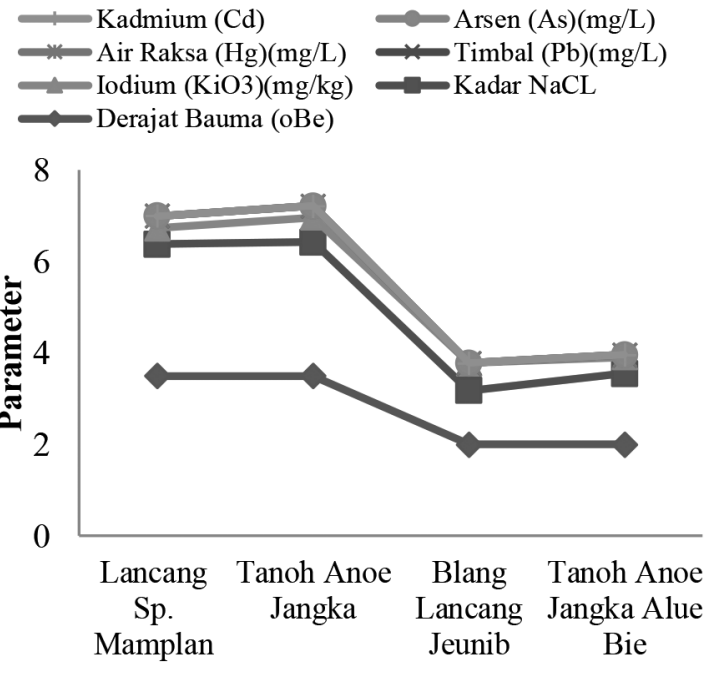

Gambar 3. Hasil uji kualitas air garam di Kabupaten Biruen 


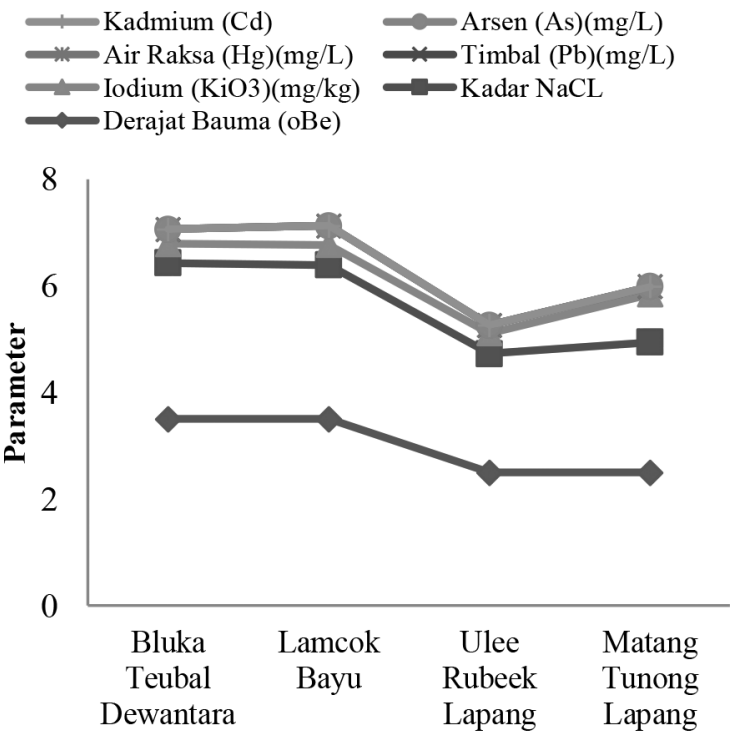

Gambar 4. Hasil uji kualitas air garam di Kabupaten Aceh Utara

\section{Metode Penelitian}

Penelitian ini dilakukan dengan pengambilan sampel di 25 titik lokasi di Provinsi Aceh. Pengambilan sampel dilaksanakan pada minggu pertama bulan September 2017 di delapan kabupaten pesisir yaitu Kabupaten Pidie, Pidie Jaya, Bireuen, Aceh Utara, Aceh Timur, Aceh Selatan, Aceh Barat Daya dan Aceh Besar. Semua kabupaten tersebut, akan dikembangkan menjadi sentra produksi garam di Provinsi Aceh.

Metode yang digunakan untuk pengumpulkan data dan informasi yaitu :

1. Pelaksanaan kegiatan survei

Dalam melaksanakan survei, dilakukan wawancara dengan petani garam. Survei dilakukan untuk mendapatkan informasi yang relevan. Responden dipilih berdasarkan lokasi yang telah ditentukan.

2. Uji laboratorium

Pengukuran kualitas air laut sebagai air tua bahan baku garam dilakukan uji laboratorium terhadap kualitas air garam tersebut. Ada tujuh parameter yang diukur untuk melihat kualitas air garam di delapan kabupaten di Aceh dengan mengambil 25 sampel. Uji Laboratorium dilakukan pada Badan Penelitian dan Pengembangan Industri Balai Riset dan Standarisasi Industri Banda Aceh.

3. Penyusunan laporan

Data yang diperoleh ditabulasikan dalam bentuk grafik, dianalisis dan dibahas secara deskriptif untuk memberikan informasi usaha pembuatan garam rakyat pada masing-masing kabupaten yang telah disurvei.

\section{Hasil Dan Pembahasan}

Pengambilan sampel di Kabupaten Pidie sebanyak enam titik. Hasil uji sampel diperlihatkan pada Gambar 1.

Gambar 1. menjelaskan hasil uji Derajat Bauma paling tinggi di 4 titik lokasi yaitu Blang Paseh, Gp. Ara Kembang Tanjong, Ceubrek Simpang Tiga dan Batee Muara Tiga masing-masing sebesar 3,5 ${ }^{\circ} \mathrm{Be}$. Selanjutnya kadar $\mathrm{NaCl}$ paling besar berada di Blang Paseh sebesar 2,95\%, Iodium (KiO3) kadarnya juga paling besar ada pada sampel Blang Paseh Kota Sigli sebesar $0,4 \mathrm{mg} / \mathrm{kg}$. Hasil uji timbal $(\mathrm{Pb})$ paling besar berasal dari sampel Rungkom Batee sebesar 0,3737 mg/L. Selanjutnya hasil uji Kadmium (Cd), Air Raksa (Hg) dan Arsen (As) dengan metode AAS berada pada posisi batas deteksi alat uji masing-masing sebesar $<$ $0,0004 \mathrm{mg} / \mathrm{L},<0,0005 \mathrm{mg} / \mathrm{L}$ dan $<0,0002 \mathrm{mg} / \mathrm{L}$.

Pengambilan sampel di Kabupaten Pidie Jaya sebanyak tiga titik. Hasil uji sampel diperlihatkan pada Gambar 2.

Gambar 2. menjelaskan hasil uji Derajat Bauma paling tinggi di 2 titik yaitu Lancang Paru Bandar Baru dan Grong-Grong Capu Ulim masing-masing sebesar 3,5 ${ }^{\circ} \mathrm{Be}$. Selanjutnya kadar $\mathrm{NaCl}$ paling besar berada di Lancang Paru sebesar 2,95\%, Iodium (KiO3) kadarnya juga paling besar ada pada sampel Lancang Paru sebesar 0,4 mg/kg. Hasil uji timbal $(\mathrm{Pb})$ paling besar berasal dari sampel Grong-Grong Capu Uli sebesar 0,3699 mg/L. Selanjutnya hasil uji Kadmium (Cd), Air Raksa (Hg) dan Arsen (As) dengan metode AAS berada pada posisi batas deteksi alat uji masingmasing sebesar $<0,0004 \mathrm{mg} / \mathrm{L},<0,0005 \mathrm{mg} / \mathrm{L}$ dan $<$

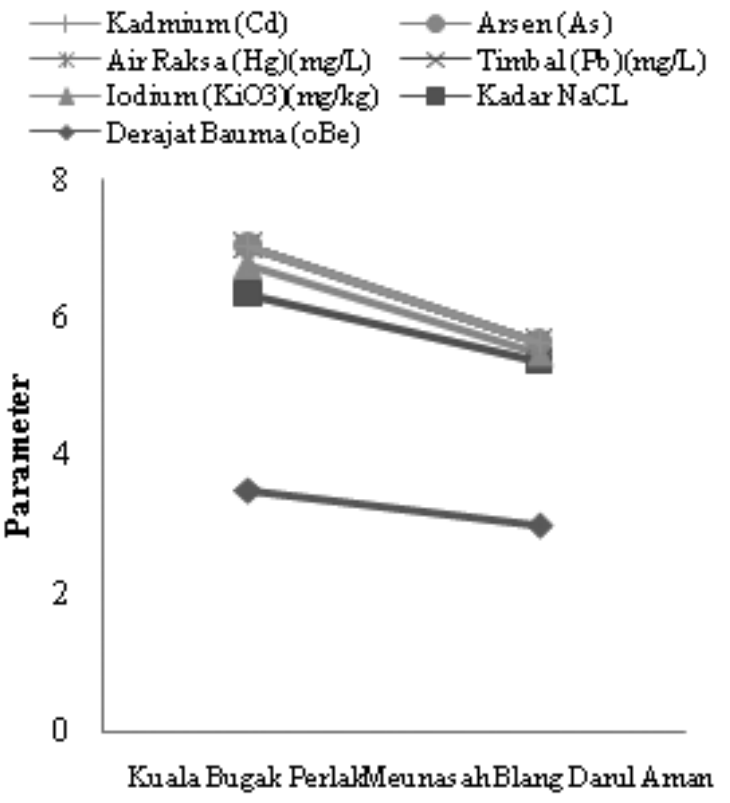

Gambar 5.Hasil uji kualitas air garam di Kabupaten Aceh Timur 


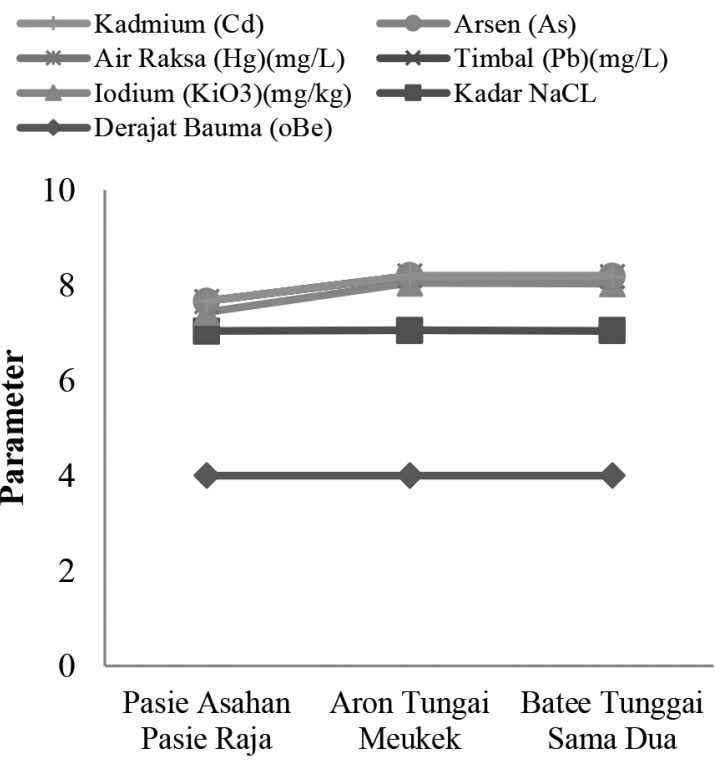

Gambar 6. Hasil uji kualitas air garam di Kabupaten Aceh Selatan

\section{0,0002 mg/L.}

Pengambilan sampel di Kabupaten Bireuen sebanyak empat titik. Hasil uji sampel diperlihatkan pada Gambar 3.

Gambar 3. menjelaskan hasil uji Derajat Bauma paling tinggi di 2 lokasi yaitu Lancang Sp. Mamplam dan Tanoh Anoe Jangka masing-masing sebesar 3,5 ${ }^{\circ} \mathrm{Be}$. Selanjutnya kadar $\mathrm{NaCl}$ paling besar berada di Tanoh Anoe sebesar 2,93\%, Iodium (KiO3) kadarnya juga paling besar ada pada sampel Blang Lancang Jeunib sebesar $0,6 \mathrm{mg} / \mathrm{kg}$. Hasil uji timbal $(\mathrm{Pb})$ paling besar berasal dari sampel Lancang Sp. Mamplam sebesar 0,2714 mg/L. Selanjutnya hasil uji Kadmium (Cd), Air Raksa (Hg) dan Arsen (As) dengan metode AAS berada pada posisi batas deteksi alat uji masingmasing sebesar $<0,0004 \mathrm{mg} / \mathrm{L},<0,0005 \mathrm{mg} / \mathrm{L}$ dan $<$ $0,0002 \mathrm{mg} / \mathrm{L}$.

Pengambilan sampel di Kabupaten Aceh Utara sebanyak enam titik. Hasil uji sampel diperlihatkan pada Gambar 4.

Gambar 4. menjelaskan hasil uji Derajat Bauma paling tinggi di 2 titik lokasi yaitu Bluka Teubal Dewantara dan Lamcok Bayu masing-masing sebesar 3,5 ${ }^{\circ} \mathrm{Be}$. Selanjutnya kadar $\mathrm{NaCl}$ paling besar berada di Bluka Teubal Dewantara sebesar 2,93\%, Iodium (KiO3) kadarnya juga paling besar ada pada sampel Matang Tunong Lapang sebesar $0,9 \mathrm{mg} / \mathrm{kg}$. Hasil uji timbal $(\mathrm{Pb})$ paling besar berasal dari sampel Lamcok Bayu sebesar 0,3591 $\mathrm{mg} / \mathrm{L}$. Selanjutnya hasil uji Kadmium (Cd), Air Raksa (Hg) dan Arsen (As) dengan metode AAS berada pada posisi batas deteksi alat uji masing-masing sebesar $<0,0004 \mathrm{mg} / \mathrm{L}$, $<$
0,0005 mg/L dan $<0,0002 \mathrm{mg} / \mathrm{L}$.

Pengambilan sampel di Kabupaten Aceh Timur sebanyak dua titik. Hasil uji sampel diperlihatkan pada Gambar 5.

Gambar 5 menjelaskan hasil uji Derajat Bauma paling tinggi di 2 titik lokasi yaitu Kuala Bugak Perlak sebesar 3,5 ${ }^{\circ} \mathrm{Be}$. Selanjutnya kadar $\mathrm{NaCl}$ paling besar berada di Kuala Bugak Perlak sebesar 2,84\%, Iodium (KiO3) kadarnya juga paling besar ada pada sampel Kuala Bugak Perlak sebesar 0,4 mg/kg. Hasil uji timbal $(\mathrm{Pb})$ paling besar berasal dari sampel Kuala Bugak Perlak sebesar 0,2909 mg/L. Selanjutnya hasil uji Kadmium (Cd), Air Raksa (Hg) dan Arsen (As) dengan metode AAS berada pada posisi batas deteksi alat uji masing-masing sebesar $<0,0004 \mathrm{mg} / \mathrm{L}$, < $0,0005 \mathrm{mg} / \mathrm{L}$ dan $<0,0002 \mathrm{mg} / \mathrm{L}$.

Pengambilan sampel di Kabupaten Aceh Selatan sebanyak tiga titik. Hasil uji sampel diperlihatkan pada Gambar 6.

Gambar 6. menjelaskan hasil uji Derajat Bauma ketiga lokasi sampel sama tingginya yaitu Pasie Asahan Pasie Raja, Aron Tunggai Mukek dan Batee Tunggai Sama Dua sebesar $4{ }^{\circ}$ Be. Selanjutnya kadar $\mathrm{NaCl}$ paling besar berada di Aron Tunggai Mukek sebesar 3,05\%, Iodium (KiO3) kadarnya juga paling besar ada pada dua sampel lokasi yaitu Aron Tunggai Mukek dan Batee Tunggai Sama Dua sebesar 0,99 $\mathrm{mg} / \mathrm{kg}$. Hasil uji timbal $(\mathrm{Pb})$ paling besar berasal dari sampel Pasie Asahan Pasie Raja sebesar 0,2324 mg/L. Selanjutnya hasil uji Kadmium (Cd), Air Raksa (Hg) dan Arsen (As) dengan metode AAS berada pada posisi batas deteksi alat uji masing-masing sebesar $<$ $0,0004 \mathrm{mg} / \mathrm{L},<0,0005 \mathrm{mg} / \mathrm{L}$ dan $<0,0002 \mathrm{mg} / \mathrm{L}$.

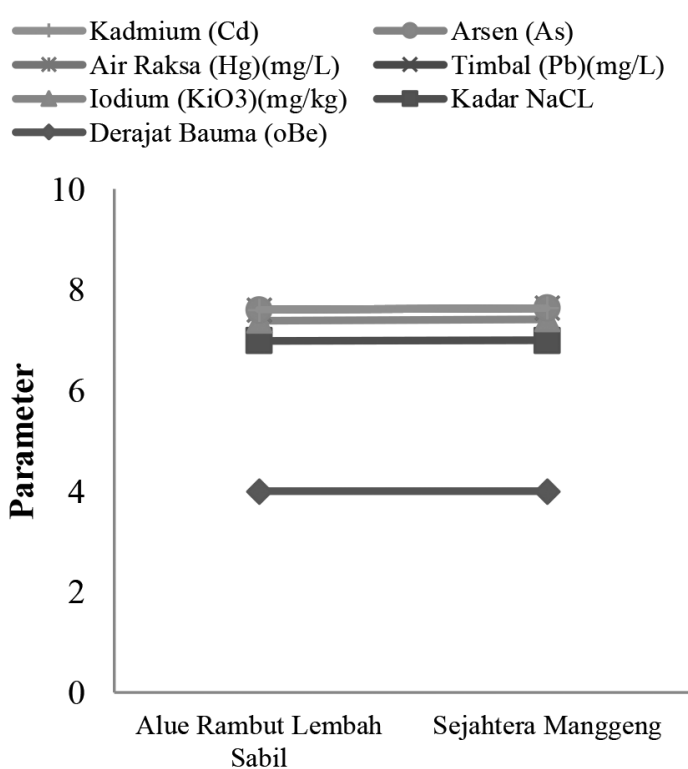

Gambar 7. Hasil uji kualitas air garam di Kabupaten Aceh Barat Daya 

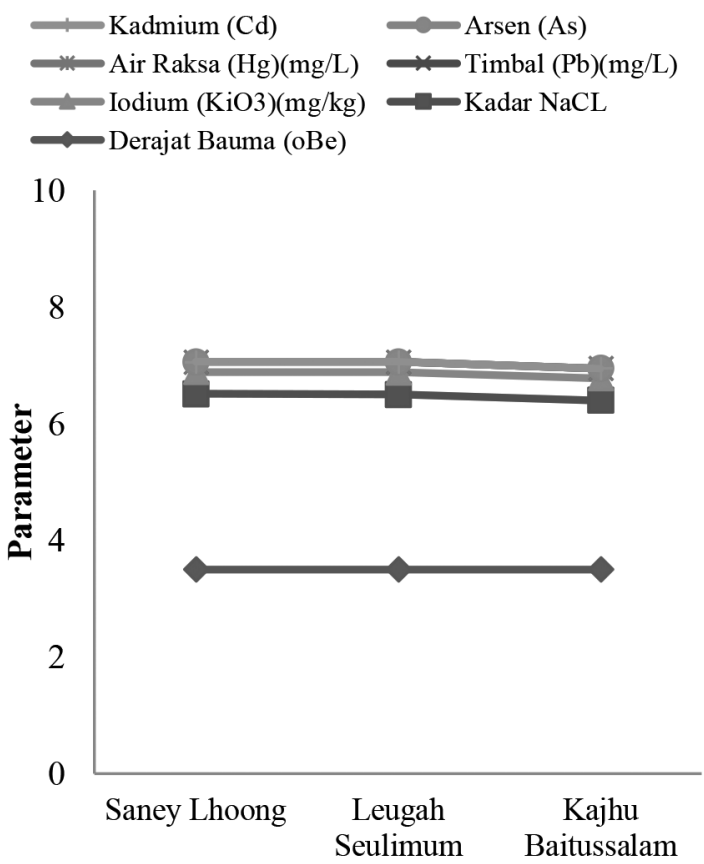

Gambar 8. Hasil uji kualitas air garam di Kabupaten Aceh Besar

Pengambilan sampel di Kabupaten Aceh Barat Daya sebanyak dua titik. Hasil uji sampel diperlihatkan pada Gambar 7

Gambar 7 menjelaskan bahwa hasil uji Derajat Bauma ketiga lokasi sampel sama tingginya yaitu Alue Rambut Lembah Sabil dan Sejahtera Mangeng sebesar $4{ }^{\circ} \mathrm{Be}$. Selanjutnya kadar $\mathrm{NaCl}$ paling besar berada di Sejahtera Mangeng sebesar 3\%, Iodium (KiO3) kadarnya pada sampel lokasi yaitu Sejahtera Mangeng sebesar $0,421 \mathrm{mg} / \mathrm{kg}$. Hasil uji timbal $(\mathrm{Pb})$ paling besar berasal dari sampel Sejahtera Mangeng sebesar 0,2224 mg/L. Selanjutnya hasil uji Kadmium (Cd), Air Raksa (Hg) dan Arsen (As) dengan metode AAS berada pada posisi batas deteksi alat uji masingmasing sebesar $<0,0004 \mathrm{mg} / \mathrm{L},<0,0005 \mathrm{mg} / \mathrm{L}$ dan $<$ $0,0002 \mathrm{mg} / \mathrm{L}$.

Pengambilan sampel di Kabupaten Aceh Besar sebanyak tiga titik. Hasil uji sampel diperlihatkan pada Gambar 8.

Gambar 8. menjelaskan hasil uji Derajat Bauma ketiga lokasi sampel sama tingginya yaitu Saney Lhoong, Leugah Seulimum dan Kajhu Baitussalam sebesar 3,5 ${ }^{\circ} \mathrm{Be}$. Selanjutnya kadar $\mathrm{NaCl}$ paling besar berada di Saney Lhoong sebesar 3,01\%, Iodium (KiO3) kadarnya ketiga lokasi sampel sama tingginya yaitu Saney Lhoong, Leugah Seulimum dan Kajhu Baitussalam sebesar $0,38 \mathrm{mg} / \mathrm{kg}$. Hasil uji timbal $(\mathrm{Pb})$ paling besar berasal dari sampel Leugah Seulimum sebesar $0,1823 \mathrm{mg} / \mathrm{L}$. Selanjutnya hasil uji Kadmium (Cd), Air Raksa (Hg) dan Arsen (As) dengan metode AAS berada pada posisi batas deteksi alat uji masing- masing sebesar $<0,0004 \mathrm{mg} / \mathrm{L},<0,0005 \mathrm{mg} / \mathrm{L}$ dan $<$ $0,0002 \mathrm{mg} / \mathrm{L}$.

\section{Kesimpulan Dan Saran}

\subsection{Kesimpulan}

1. Derajat Bauma ketiga lokasi sampel sama tingginya yaitu Alue Rambut Lembah Sabil dan Sejahtera Mangeng sebesar $4^{\circ}$ Be. Selanjutnya kadar $\mathrm{NaCl}$ paling besar berada di Sejahtera Mangeng sebesar 3\%, Iodium (KiO3) kadarnya pada sampel lokasi yaitu Sejahtera Mangeng sebesar $0,421 \mathrm{mg} / \mathrm{kg}$.

2. Hasil uji timbal $(\mathrm{Pb})$ paling besar berasal dari sampel Sejahtera Mangeng sebesar 0,2224 mg/L. Selanjutnya hasil uji Kadmium (Cd), Air Raksa (Hg) dan Arsen (As) dengan metode AAS berada pada posisi batas deteksi alat uji masing-masing sebesar $<0,0004 \mathrm{mg} / \mathrm{L},<0,0005 \mathrm{mg} / \mathrm{L}$ dan $<$ $0,0002 \mathrm{mg} / \mathrm{L}$.

\subsection{Saran}

Demi menjaga kualitas garam diharapkan kepada semua pihak agar tidak membuang limbah sembarangan sehingga mencemari air laut yang akan digunakan sebagai air tua bahan baku garam rakyat.

\section{Ucapan Terima Kasih}

Ucapan terima kasih kepada tim Dinas Kelautan dan Perikanan Aceh yang telah melakukan survey lapangan. Kajian ini merupakan kegiatan pada mata anggaran Bidang Program Pemberdayaan Ekonomi Masyarakat Pesisir, Dinas Kelautan dan Perikanan Aceh, Tahun Anggaran 2018.

\section{Daftar Pustaka}

Anandraj,A.,D.J.Marshall, M.A. Gregory, T.P.M.Cclung. 2002. Metal accumulation, filtration, and $\mathrm{O} 2$ uptake rate in the mussel Perna perna (Molusca: Bivalvia) exposed to $\mathrm{Hg} 2+, \mathrm{Cu} 2+$, and $\mathrm{Zn} 2+$. Comparative Biochemistry and Physiology. Part C. 132: 355-363.

Andersen, V., A. Maage, P.J. Johannensen. 1996. Heavy metals in blue mussels (Mytilus edulis) in the Bergen Harbor area, Western Norway. Bulletin Environmental Contamination Toxicology 57: 589-596.

Burhanuddin. 2001. Strategi Pengembangan Industri Garam di Indonesia, Kanisius, Yogyakarta.

Barus, T. A, 2003, Pengantar Limnologi, Jurusan Biologi FMIPA USU, Medan.

Cotton dan Wilkinson, 1989, Kimia Anorganik Dasar, Universitas Indonesia, Jakarta.

Darmono, 1995,Logam Dalam Sistem Biologi Makhluk 
Hidup, Penerbit UI- Press, Jakarta.

Dini Purbani, 2006. Kristalisasi Garam. Badan Riset Kelautan dan Perikanan Jakarta, Kementerian kelautan dan Perikanan.

Direktorat Kimia Hilir Kementerian Perindustrian, 2011, www.kemenperin.go.id/artikel/45/KemenperinGenjot-Produksi-Garam-Nasional, di akses tanggal 20 Juni 2019.

Effendi. H, 2003. Telaah Kualitas Air, Kanisius, Yogyakarta.

Jumaeri, dkk, 2003. Pengaruh Penambahan Bahan Pengikat Impurities terhadap Kemurnian Natrium Klorida Pada Proses Pemurnian Garam Dapur Melalui Proses Kristalisasi, Laporan Penelitian ,Lembaga Penelitian UNNES, Semarang.

Rahmat Al. Ramard A, 2016, Kadar Pencemaran Logam Berat Timbal $(\mathrm{Pb})$, Merkuri $(\mathrm{Hg})$ dan Seng $(\mathrm{Zn})$ pada Tanah di Sekitar Rumah Susun Pantai Losari Kota Makassar, Skripsi, Fakultas Sains dan Teknologi, UIN Alauddin, Makassar.

Sihotang, C. Dan Efawani, 2006, Penuntun Praktikum Limnologi, Fakultas Perikanan dan Ilmu Kelautan UNRI: Pekanbaru, 26 hal.

Subarijanti, H. U, 2005, Pemupukan dan Kesuburan Perairan, Fakultas Pertikanan, Universitas Brawijaya, Malang.

Sutrisnanto Danny. 2001. Persiapan Lahan dan Sarana Penunjang untuk Garam dan Tambak, Kementerian Perindustrian dan Perdagangan, Jakarta.

Syukur, A. 2002, Kualitas Air dan Struktur Komunitas Phytoplankton di Waduk Uwai, Skripsi Fakultas Perikanan dan Ilmu Kelautan Universitas Riau, Pekanbaru, 51 hal. 